\title{
Borrowed Dreams: Joseph Cornell and the Archive as Psychic Imprint
}

Stephen Broomer

DOI:10.15664/fcj.v19i0.2391

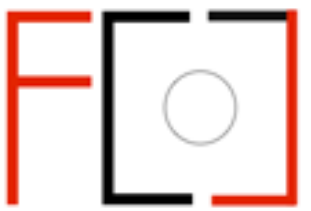

Frames Cinema Journal

ISSN 2053-8812

Issue 19 (March 2022)

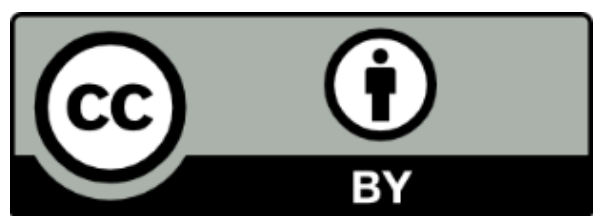


Frames Cinema Journal, Issue 19 (March 2022)

\section{Borrowed Dreams: Joseph Cornell and the Archive as Psychic Imprint}

Stephen Broomer

This video essay (Vimeo link: https://vimeo.com/685525533) is occasioned by a groundswell of scholarship on the interrelated fields of the found footage experimental film, the compilation film, and the motion picture archive. This scholarship is reflected in recent publications by Catherine Russell and Jaimie Baron and attended to in the broader critical climate by the proliferation of exhibitions and articles that have attempted in recent years to address the historical impetus for this growing body of work. The neologism archiveology denotes a practice that draws from, as Catherine Russell puts it, "an 'image bank' of collective memories," declaring that the moving image collection has been cast far from the rigid formality of the museum, and is now a process in itself of uncovering and exploring. ${ }^{1}$ Such practice finds a natural parallel in the curio-hunting Big Digs of eighteenth- and nineteenth-century colonial archaeology. The archaeological metaphor and its mystical portents are uniquely suitable for the subject at hand, Joseph Cornell, the Howard Carter of the twentieth-century American junk shop. While this video essay features discursive narration, it is simultaneously engaged in remixing the poetic properties of images - by mirroring and building upon Cornell's aesthetic strategies. In his reflections on Joseph Cornell, poet Charles Simic offers this metaphor: "the near darkness of old churches and old movies is that of dreams," a suggestion of the reciprocity between the archive and the talismanic depths of modern art. ${ }^{2}$

Joseph Cornell remains most widely recognised for his boxed assemblages. The neglect of his films relative to his boxes may invite dismissal as novelty, as a prototype for what would follow, be that the found footage experimental film, or in more contemporary terms, fandom and the 
supercut. In response to this limited perspective, Borrowed Dreams begins with a prologue that joins crucial passages from Cornell's Rose Hobart (1936) with dialogue from its source, East of Borneo (1931). Much has been made of the identification between Cornell and Hobart, of Hobart as symbol and as a woman recovered from the artifice of cinema itself, what Catherine Russell has identified as "the awakening of the woman and an inscription of her everyday humanity into film history." ${ }^{3}$ However, Rose Hobart has eclipsed both its namesake and the film from which it is derived. This prologue, in which Linda Randolph (Rose Hobart) empathises with a chimp over their shared predicament of being held against their will, underscores not only themes that are poignant in light of Cornell's project ("they like making things captive in this place"), but is also likely to give the majority of viewers their first experience of hearing Hobart's voice. Such is the neglect of her own work, in the shadow of Cornell's tribute to her face.

Borrowed Dreams explores the foundations of Cornell's filmmaking, focusing on his films that are most open in their construction - those begun in his pre-war phase, often imprecisely dated and, in some cases, abandoned for decades. ${ }^{4}$ This video essay inquires into his process, theme, and technique, and in doing so, it offers the archive as a site of psychic provocation. It considers Cornell's processes of collaboration and interaction with the image, with history, and with individuals. It addresses his themes of sacred innocence found in the avatars and entertainments of children. Finally, it addresses his use of a plate of tinted glass to cast a nocturnal atmosphere onto the image, and his use of the splice as a means to join disparate spaces (as in Kuleshov's concept of creative geography) and eyelines (as in Kuleshov's theory of montage), a simple means of opening onto new perceptions. Cornell's splice, made with an openness to the inference of the viewer, plots new and flexible meanings into his root images. ${ }^{5}$ It is this last matter, of technique, that is communicated formally throughout Borrowed Dreams, a means of clarifying Cornell's 
approach, which Marjorie Keller has described as an equivocating edit, by remixing his films and integrating them with other related objects of study. This can be seen in the intercutting of $U n$ Chien Andalou with Rose Hobart, through which Pierre Batcheff and Luis Buñuel both stand in for temperamental Salvador Dalì as they observe Hobart, and in the intercutting of naval scenes from The Fall of the Romanov Dynasty (1927) with scenes of marine exploration taken from Cornell's Bookstalls (ca. 1930s). Such splices demonstrate the psychic impressions that appropriated images conjure when positioned in new sequences.

The structure of this video essay is episodic, with each of its three parts dealing with a distinctive aspect of Cornell's films. Part one, preceding and following a quotation from Jodi Hauptman on the thematic potency of the eclipse, deals with Rose Hobart, its relation to Surrealism, the particular impact of its gesture, and the nocturnal spell of its tinting. Part two, marked by a quotation from Standish Lawder on the ambiguous purpose of the recycled image, deals with the legacy of the compilation film and Cornell's formal and thematic distinction from that field and, in particular, the work of Esfir Shub. Part three begins with a quotation from Marjorie Keller, on Cornell's approach to editing as a means of equivocating subjects, and it involves the material Keller was primarily responding to, the films known as The Children's Trilogy (ca. 1940s, finished 1969), bringing them into dialogue with the concept of deriving meaning from the impact of sequential ordering.

Borrowed Dreams argues on behalf of the unique power of the hard cut, of a splice to join presences across space and time. The splice is integral to the psychic properties of Cornell's work, which ties his films to the oneiric dimensions of the Surrealists and to the psychological interiority of the American trance film. ${ }^{6}$ The imagery and atmosphere that he develops may suggest reverie 
or the dream, while the hard cut is an unambiguous act of cinema. Those closest to Cornell have attested in the years since his death that he occupied "the thin line between dreaming and waking."7 The bulk of Cornell's films liberally borrow from scraps of industrial cinema, but there is no illusion of what Jaimie Baron refers to as the "truth-value" and "evidentiary authority" of the archival image, with Cornell focused solely on the patterns and relations formed by newfound contexts. ${ }^{8}$ The psychic imprint of the archival image holds through his disciplined restraint and the slow unfolding of imagery in long and patient takes, an operation brought on by the complex interiority of shot relations. The found footage film would shift in another direction forty years after Rose Hobart, influenced by the unlikely combination of both Stan Brakhage and the structuralists, abandoning the psychic trinity of Cornell and his successors Bruce Conner and Arthur Lipsett (an archival cinema that gives way instead to the readymade form of the "perfect film", via Ken Jacobs) in favour of a plastic turn, marking the image in violent ways with paint and chemistry, or by further machining an image's rhythm through optical printers. These psychic and plastic strains in found footage filmmaking can be best understood in relationship to one another, with the psychic interiorising history and images past, and the plastic externalising the rage and pleasure of the present moment.

In the oneiric patchwork of his subject matter, Cornell invites comparisons to his contemporaries and fellow New Yorkers Joe Gould and Harry Smith, amateur archivists of a similar mentality for whom daily experience became a storehouse of observations worthy of transcription and recall. Cornell's relation to his materials might be further clarified by considering the collections of Gould and Smith. Gould, notoriously exposed as the naked emperor of Greenwich Village, had claimed to have spent decades writing An Oral History of Our Time. It was endorsed by his patrons and friends as an epic work, but when he died it came out that there was no intact manuscript. ${ }^{9}$ Smith, 
known between spheres as one of American folk culture's great chroniclers and as a maker of experimental films, is also known to have collected string figures and paper airplanes and other, more sundry and intimate specimens. ${ }^{10}$ As Borrowed Dreams demonstrates in the thread of his recycled images, Cornell, like Gould and Smith, maintained a passion for the ephemeral. Cornell's films had transient, anonymous, dreamlike tendencies that testify to a willingness he had, by contrast to Smith and in accord with Gould, to loosen the reins, to allow the debris of incomplete gestures to gather in his wake.

\section{Notes}

${ }^{1}$ Catherine Russell, Archiveology: Walter Benjamin and Archival Film Practices (Durham, NC: Duke University Press, 2018), 1.

${ }^{2}$ Charles Simic, Dime-Story Alchemy: The Art of Joseph Cornell (Hopewell, NJ: Ecco Press, 1992), 57.

${ }^{3}$ Russell, 205.

${ }^{4}$ Without a definitive catalogue raisonné of his films, Cornell's consideration by archives is far from authoritative. In the absence of authority, objects from Cornell's film collection, works in progress, and possibly finished films have all at times been treated as finished works, as in the case of The Children's Jury, dated 1938 but only regarded as 'attributed to' Cornell.

5 Throughout Borrowed Dreams and in this text, Cornell's work features in a context that includes Soviet compilation filmmaking and montage theory; while there are no definitive claims to be made about his awareness of the dynamic strategies developing in Russia, it seems likely from his broad reading, his moviegoing, and his friendships with critics such as Jay Leyda that he would have an active awareness of the discourse. This work makes no claim that Cornell is interacting with these theories with intention, let alone precision: Cornell's filmmaking, judging by the films he made alone - Rose Hobart, Bookstalls, By Night with Torch and Spear - was intuitive and improvisatory, not an act of theoretical proofing.

${ }^{6} \mathrm{P}$. Adams Sitney, who coined the term, defines the trance film as featuring "a somnambulistic hero wandering through an imposing landscape." P. Adams Sitney, "The Idea of Morphology," Film Culture 53-55 (Spring 1972).

${ }^{7}$ Catherine Corman, Joseph Cornell's Dreams (Cambridge, MA: Exact Change, 2007), 134. Corman quotes Lawrence Jordan at length, as he describes Cornell's navigation of dream and waking life: "He took naps on the front room sofa for three or four hours and would get up directly out of a dream and put something together. He didn't come out of that world like you or I do."

${ }^{8}$ Jaimie Baron, The Archive Effect: Found Footage and the Audiovisual Experience of History (London: Routledge, 2014).

${ }^{9}$ Gould, made famous and exposed through Joseph Mitchell's Joe Gould's Secret, was defended in Jill Lepore's Joe Gould's Teeth (New York, NY: Alfred A. Knopf, 2016), which provides evidentiary benchmarks for the premise that Gould's manuscript existed in many different forms over decades. 
${ }^{10}$ Smith's collections present a fascinating challenge to valuations of objects in relation to the history of the motion picture. An argument could be made that his collections of paper string figures and paper airplanes are, as dynamic found objects, paracinematic.

\section{Bibliography}

Baron, Jaimie. The Archive Effect: Found Footage and the Audiovisual Experience of History. London: Routledge, 2014.

Corman, Catherine. Joseph Cornell's Dreams. Cambridge, MA: Exact Change, 2007.

Dyshlyuk, Liubov. "Esfir Shub: Selected Writings.” Feminist Media Histories 2 (3) (2016): 1128.

Hauptman, Jodi. Joseph Cornell: Stargazing in the Cinema. New Haven, CT: Yale University Press, 1999.

Keller, Marjorie. The Untutored Eye: Childhood in the Films of Cocteau, Cornell, and Brakhage. Rutherford, NJ: Fairleigh Dickinson University Press, 1986.

Lawder, Standish. "Comments on the Collage Film," in Found Footage Film. Lucerne: VIPER/zyklop, 1992.

Lepore, Jill. Joe Gould's Teeth. New York, NY: Alfred A. Knopf, 2016.

Leyda, Jay. Films Beget Films: a study of the compilation film. New York, NY: Hill and Wang, 1964.

Russell, Catherine. Archiveology: Walter Benjamin and Archival Film Practices. Durham, NC: Duke University Press, 2018.

Simic, Charles. Dime-Story Alchemy: The Art of Joseph Cornell. Hopewell, NJ: Ecco Press, 1992. 


\section{Filmography}

Auguste and Louis Lumìere, L'Arrivée d'un train en gare de La Ciotat, directed by Auguste and Louis Lumìere (1895; La Ciotat; Société Lumière; home video release 2015), 35mm.

Frederick S. Armitage, Davy Jones 's Locker, directed by Frederick S. Armitage (1903; production location unknown; American Mutoscope \& Biograph; home video release 2008), 35mm.

Frederick S. Armitage, Neptune's Daughters, directed by Frederick S. Armitage (1903; production location unknown; American Mutoscope \& Biograph; home video release 2008), $35 \mathrm{~mm}$.

Frederick S. Armitage, Nymph of the Waves, directed by Frederick S. Armitage (1903; production location unknown; American Mutoscope \& Biograph; home video release 2008), $35 \mathrm{~mm}$.

Esfir Shub, The Fall of the Romanov Dynasty, directed by Esfir Shub (1927; Moscow; Sovkino; home video release 2002), $35 \mathrm{~mm}$.

Luis Buñuel and Salvador Dalì, Un chien andalou, directed by Luis Buñuel (1929; Le Havre and Paris; Les Grands Films Classiques; home video release 2011), 35mm.

Joseph Cornell, Bookstalls, directed by Joseph Cornell (undated, circa 1930s; New York; The Voyager Foundation; home video release 2004), 16mm.

George Melford, East of Borneo, directed by George Melford (1931; Los Angeles; Universal Studios; home video release 2004), 35mm.

Joseph Cornell, Rose Hobart, directed by Joseph Cornell (1936; New York; The Voyager Foundation; home video release 2004), 16mm. 
Joseph Cornell, The Children's Jury, directed by Joseph Cornell (1938; New York; ; home video release), $16 \mathrm{~mm}$.

Joseph Cornell, Cotillion, directed by Joseph Cornell (undated, circa 1940s, finished 1968; New York; The Voyager Foundation; home video release 2004), 16mm.

Joseph Cornell, The Midnight Party, directed by Joseph Cornell (undated, circa 1940s, finished 1968; New York; The Voyager Foundation; home video release 2004), 16mm.

Joseph Cornell, The Children's Party, directed by Joseph Cornell (undated, circa 1940s, finished 1968; New York; Image Entertainment; home video release 2008), 16mm.

Joseph Cornell, By Night with Torch and Spear, directed by Joseph Cornell (undated, circa 1940s, finished 1972; New York; Image Entertainment; home video release 2008), 16mm. Maya Deren, At Land, directed by Maya Deren (1944; Amangansett, Long Island; Re:voir; home video release 2020), $16 \mathrm{~mm}$.

Kenneth Anger, Fireworks, directed by Kenneth Anger (1947; Los Angeles; Puck Film Productions; home video release 2011), 16mm.

\section{Author Biography}

Stephen Broomer is a filmmaker and writer. His books include Hamilton Babylon: A History of the McMaster Film Board (University of Toronto Press, 2016) and Codes for North: Foundations of the Canadian Avant-Garde Film (CFMDC, 2017), and he is presently completing a critical biography of collage filmmaker Arthur Lipsett. His films were recently the subject of a retrospective at the Anthology Film Archives in New York City. He has taught video essaying at University of Toronto. Broomer is also the host of Art \& Trash, an ongoing web series on underground, avant-garde, psychotronic and outsider media. In 2020, he began a study of the 
Frames Cinema Journal, Issue 19 (March 2022)

poetics of home movies while serving as a Fulbright visiting scholar at University of California Santa Cruz and the Prelinger Library. Most recently, he was a postdoctoral fellow at the Centre for Canadian Studies at Brock University, sponsored by the International Council for Canadian Studies.

ORCID: 0000-0003-4923-9197 